\title{
An implementation of rock engineering system (RES) for ranking the instability potential of slopes in Greek territory. An application in Tsakona area (Peloponnese - prefecture of Arcadia)
}

\author{
Tavoularis N. ${ }^{1 *}$, Koumantakis I. ${ }^{1}$, Rozos D. ${ }^{1}$, Koukis G. ${ }^{2}$ \\ ${ }^{1}$ Department of Geological Sciences, School of Mining and Metallurgical Engineering, \\ NTUA, 9 Heroon Polytechniou str, 15780 Zografou Athens, Greece,ntavoularis@metal.ntua.gr, \\ phone number: 2132142223 / 2106930150 , \\ fax: 2106920472 \\ ${ }^{2}$ Department of Geology, University of Patras, 26504 Patras
}

\begin{abstract}
This paper presents an application of the Rock Engineering system (RES) in an attempt to assess the inherent instability potential of Tsakona landslide in the region of SW Arcadia, Peloponnese, Greece which happened on February 2003. The RESystem has been considered to fulfill the basic requirements to deal with landslide phenomena, as it combines objectivity and efficiency.

The main scope of RES application to landslide studying is to define the important causative and triggering factors responsible for the slope failures, quantify their interactions, obtain their weighted coefficients and calculate the instability index, which refers to the potential instability of the examined natural slope. In this study, the final implementation of the RES method is achieved through an interaction matrix, where ten principal parameters were selected as controlling factors for the landslide occurrence. It is concluded that RES could be a simple and efficient tool in calculating the instability index and as a consequence getting a prognosis of a potential slope failure regarding the land use and development planning processes in landslide susceptible areas.
\end{abstract}

Key words: Interaction matrix, RES, instability index, landslide susceptibility, landslide parameters

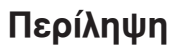

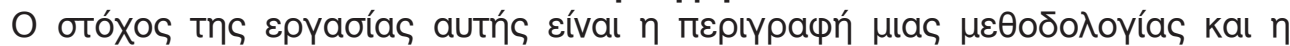

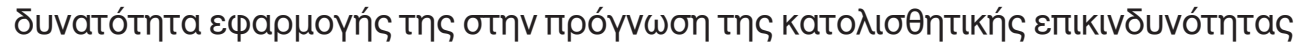

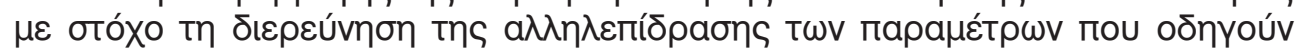

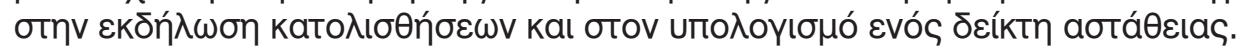

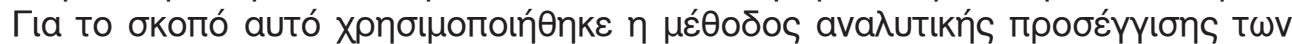

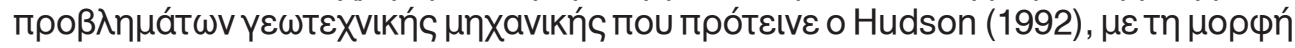

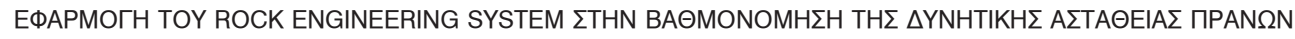

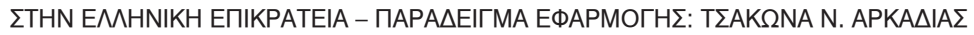

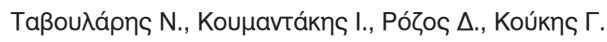




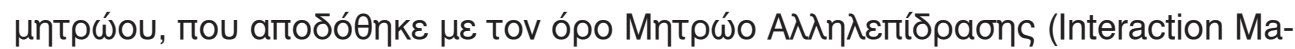

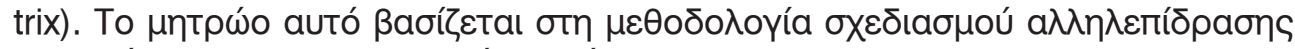

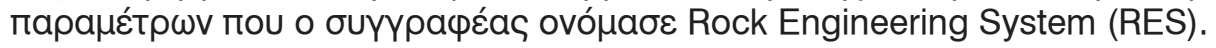

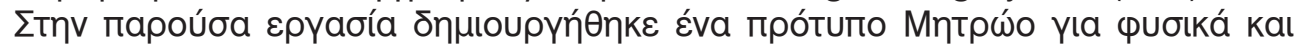

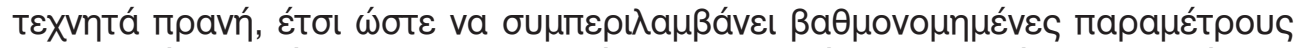

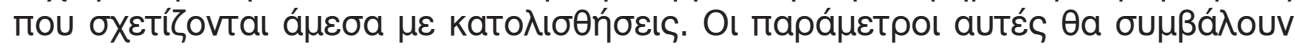

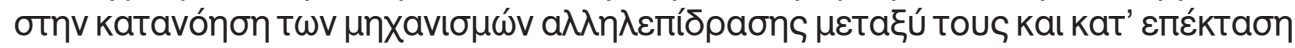

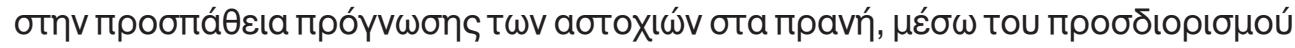

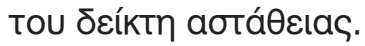

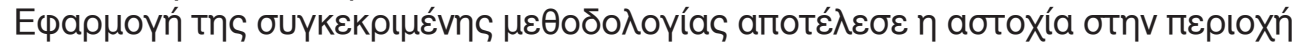

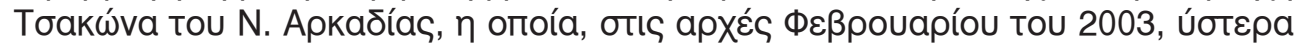

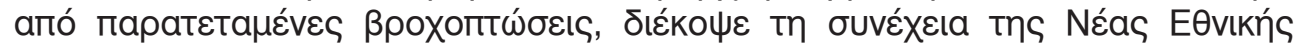

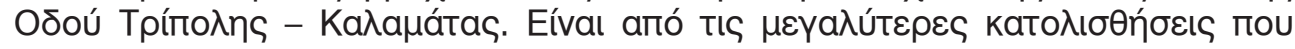

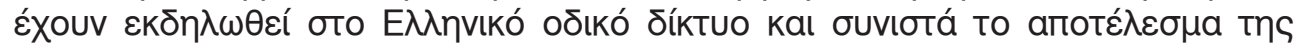

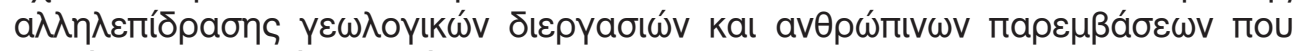
$\varepsilon \xi \varepsilon \lambda i ́ x \theta \eta$ kav $\sigma \varepsilon$ ßáӨos Xpóvou.

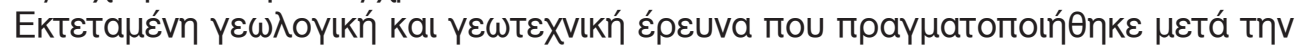

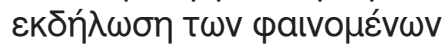

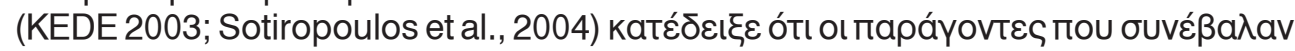

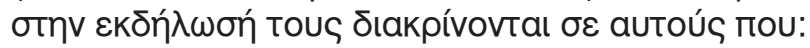

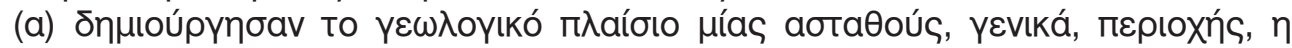

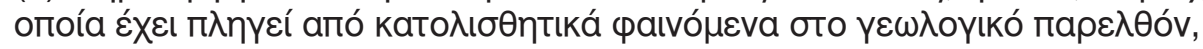

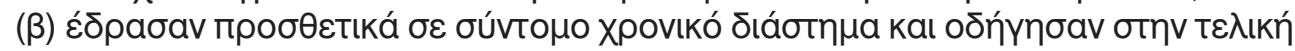

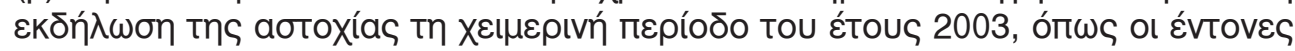

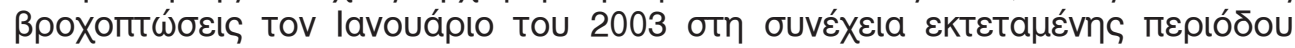

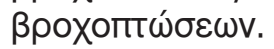

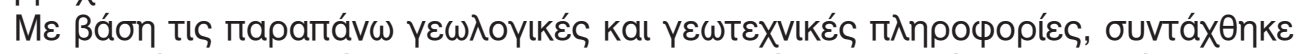

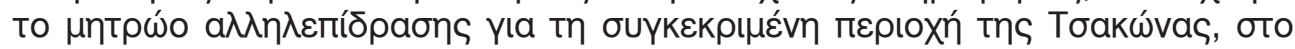

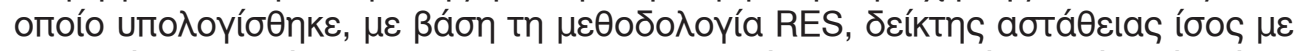

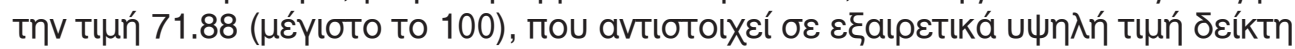

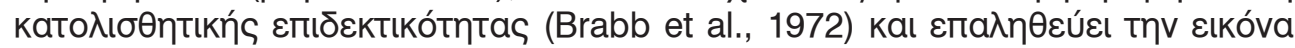

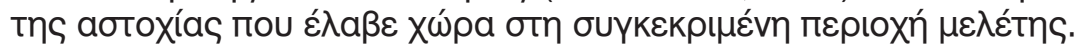

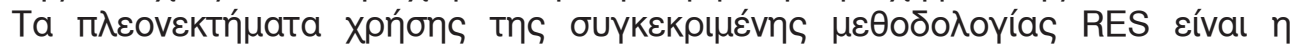

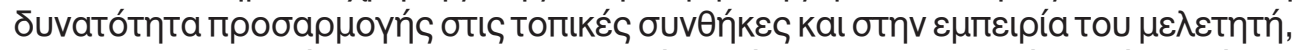

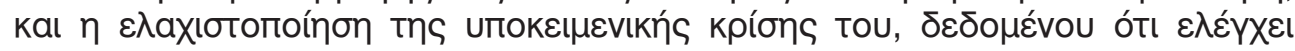

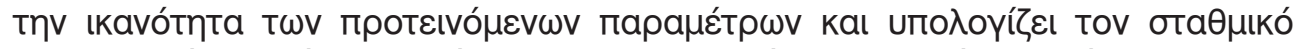

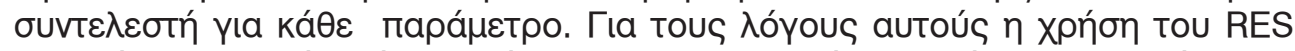

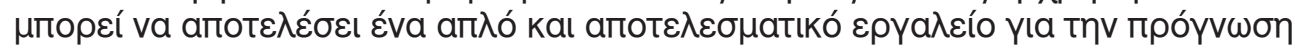

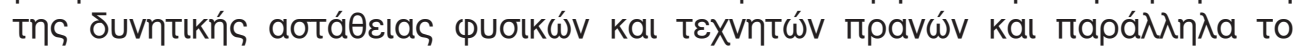

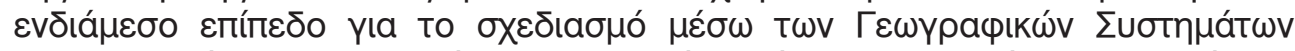

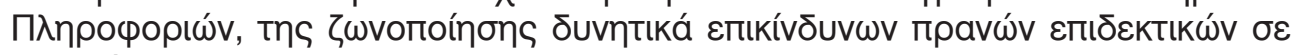
aotoxía.

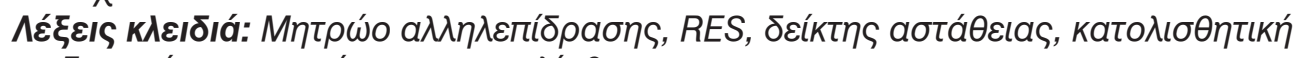

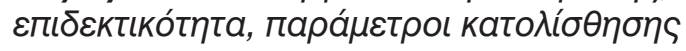




\section{Introduction}

The rapid increase in population world - wide, coupled with the migration from rural to urban areas, has meant that the creation of new settlement sites, mostly, in cities has become an urgent necessity. However, one major danger that comes out for satisfying the aforementioned need is that of landslides. For this reason, it is important that the selection of such sites should be based on geoenvironmental criteria, taking into account both a sustainable environment and disaster sensitive planning (Dai and Lee, 2001).

Landslides are characterized by uncertainties, because of the difficulties of the variability of the causative and triggering factors, which make the analyses of such phenomena a very difficult task. To deal with such events, many researchers have developed ranking assessment tools (Cai et al., 1998, Benardos and Kaliampakos, 2004). Foumelis et al., 2004, Irigaray et al., 2006, Fountoulis et al., 2007, Ceryan, 2008, Rozos et al., 2008, Van Western et al. 2010, Rozos et al., 2011).

Rapid assessment methods to ascertain the suitability of a site/region for development are not available to planners, landowners and others and for this reason, there is an urgent need to demarcate regions susceptible to slope failure with a fixed set of relevant parameters.

These parameters usually provide to the engineering geology experts a cost and time effective toolbox for tracing the most critical slope sites (appropriate for land - use planning), which exhibit high inherent instability potential.

The Rock Engineering System (RES, Hudson, 1992) has been considered to fulfill the basic requirements for developing an analogous approach to deal with landslide phenomena, as it combines objectivity and efficiency (Rozos et al., 2008).

Regarding the aforementioned, this paper presents an application of RES in an attempt to assess the inherent instability potential of Tsakona landslide in the region of SW Arcadia, Peloponnese, Greece which happened on February 2003.

The main scope has been defining the important causative and triggering factors responsible for the slope failures, quantifing their interactions, obtaining their weighted coefficients and calculating the instability index, which refers to the potential instability of the examined natural slope.

The selection of the appropriate parameters was based not only on valuable knowledge from literature and mainly on the overall experience gained from the study of landslide phenomena in Greek territory but also on their affinity with landslide occurrence in the study area.

The study concludes that RES could be a simple and efficient tool in calculating the instability index and as a consequence getting a prognosis of a potential slope failure regarding the land use and development planning (such as a highway) processes in landslide susceptible areas.

\section{The Rock Engineering System Method}

The interaction matrix is the basic tool for RES approach to geotechnical problems, representing the selected parameters as leading diagonal terms and their interactions (as off-diagonal terms). It could be mentioned that each matrix can be considered as a map (Hudson, 1992).

On Figure 1, regarding that $\mathrm{Pi}$ corresponds to a particular parameter; it is clear that the row passing through the 
Pi represents the influence of $\mathrm{Pi}$ on all the other parameters in the system. Conversely, the column through $\mathrm{Pi}$ represents the influence of the other parameters (the rest of the system) on $\mathrm{Pi}$ (Fig.1).

To quantify the result of binary interactions, a semi-quantitative coding method has been used with values ranging from 0 to 4 corresponding to no (most stable conditions), weak, medium, strong and critical interaction (most favorable condition for slope failure), re- spectively (Fig. 2).

Once the matrix has been numerically coded, the sum of each row and each column can be determined

(Figs 1 and 2). If now, we think of the influence of $\mathrm{Pi}$ on the system, we can term the sum of the row values as the "cause - C" and the sum of the column values as the "effect - $E$ ", designated as co - ordinates (C, E). Thus,

$\mathrm{C}$ represents the way in which $\mathrm{Pi}$ affects the system; and E represents the effect that the system has on Pi (Fig.1).

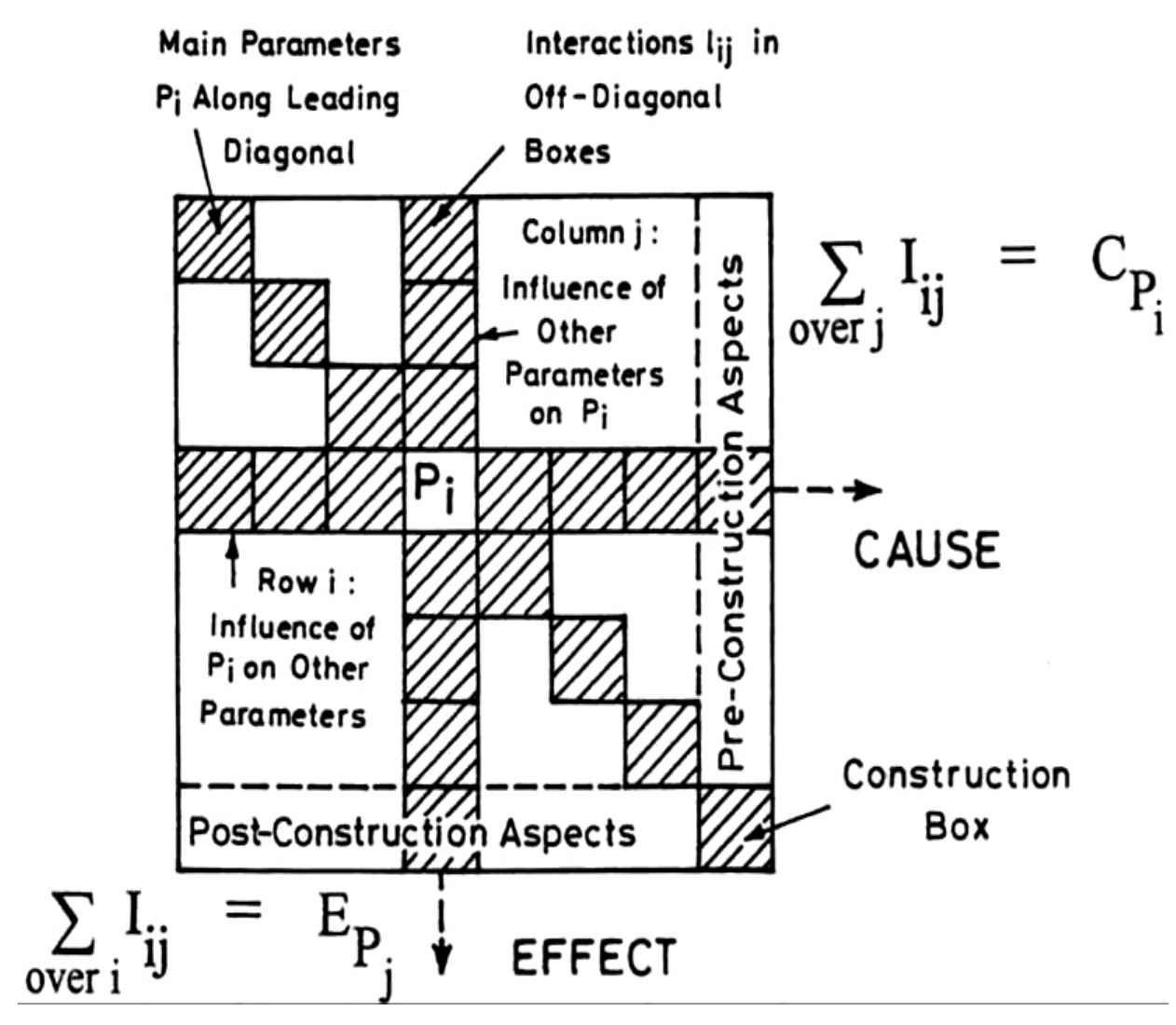

Fig. 1. Summation of coding values in the row and column through each parameter to establish the cause and effect co-ordinates (Hudson, 1992).

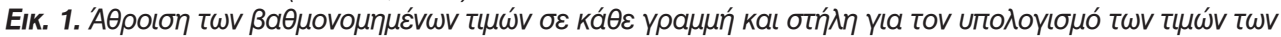

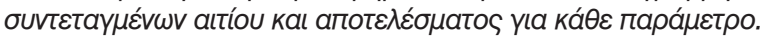




\begin{tabular}{|c|c|c|c|c|c|c|c|c|c|c|}
\hline & & & & & & & & & & \\
\hline & $\otimes$ & & & 2 & & 2 & & & 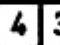 & \\
\hline & 48 & 2 & 2 & & 2 & 1 & 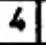 & 1 & 45 & \\
\hline & 2 & 2 & 8 & 2 & 1 & 1 & 1 & 2 & & \\
\hline & 43 & 3 & 3 & 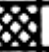 & 1 & 2 & 3 & 4 & 4 & 4 \\
\hline & \begin{tabular}{|l|}
4 \\
\end{tabular} & 1 & 2 & 3 & & 4 & 4 & 1 & 4 & 2 \\
\hline & 6 & 4 & 2 & 3 & & 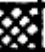 & 4 & 4 & 4 & 2 \\
\hline & 2 & 4 & 1 & 2 & 2 & 1 & 8 & 1 & & 4 \\
\hline & \begin{tabular}{|l|l|}
3 &
\end{tabular} & 3 & 4 & 3 & 1 & 1 & 4 & 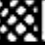 & 4 & 2 \\
\hline & \begin{tabular}{|l|l}
4 & \\
\end{tabular} & 3 & 2 & 1 & 1 & 1 & 1 & 1 & & \\
\hline & \begin{tabular}{|l|}
3 \\
\end{tabular} & 3 & 1 & 4 & 1 & 2 & 4 & 1 & 4 & \\
\hline & & & & & & & & & & \\
\hline
\end{tabular}

0_ No Interaction

1 - Weak Interaction

2 - Medium Interaction

3 - Strong Interaction

$$
4 \text { - Critical Interaction }
$$

Sums of Row and

Column Values

Gives $\mathrm{P}_{\mathrm{i}}(\mathrm{C}, \mathrm{E})$

Co-ordinates

Plotted in

Cause-Effect

Space

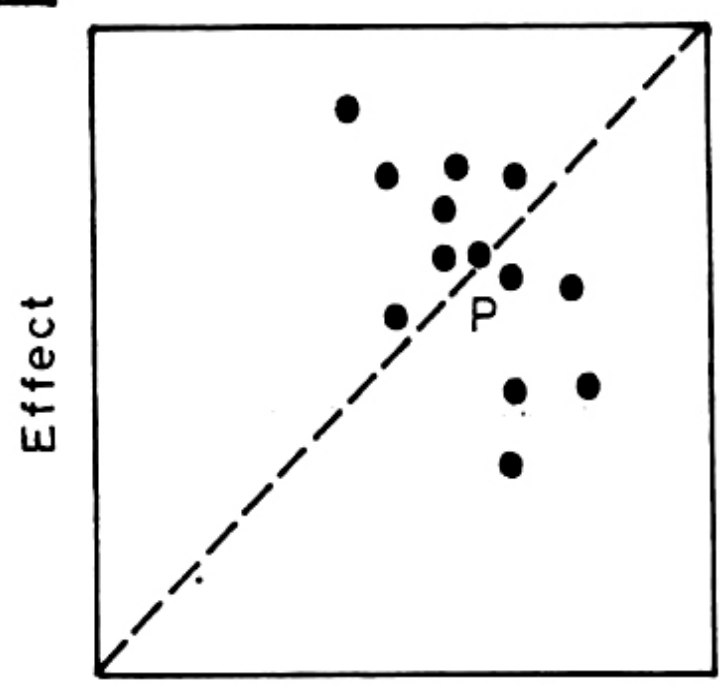

Cause

Fig. 2. Coding values for the generic slopes interaction matrix and the associated cause vs effect plot (Hudson, 1992).

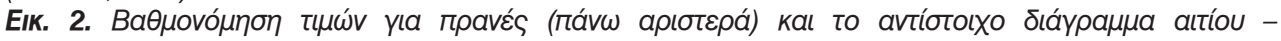

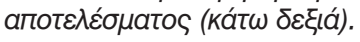

By coding the interaction matrix components and then summing the values in the row and column through each parameter, "cause" and "effect" co ordinates are generated, indicating a parameter's interaction intensity and dominance. By this, we can consider how to quantify parameter significance (Fig.3), through the two measures of parameter interaction which are intensity (as the distance along the diagonal) and dominance (the perpendicular distance from this diagonal to the parameter point). 


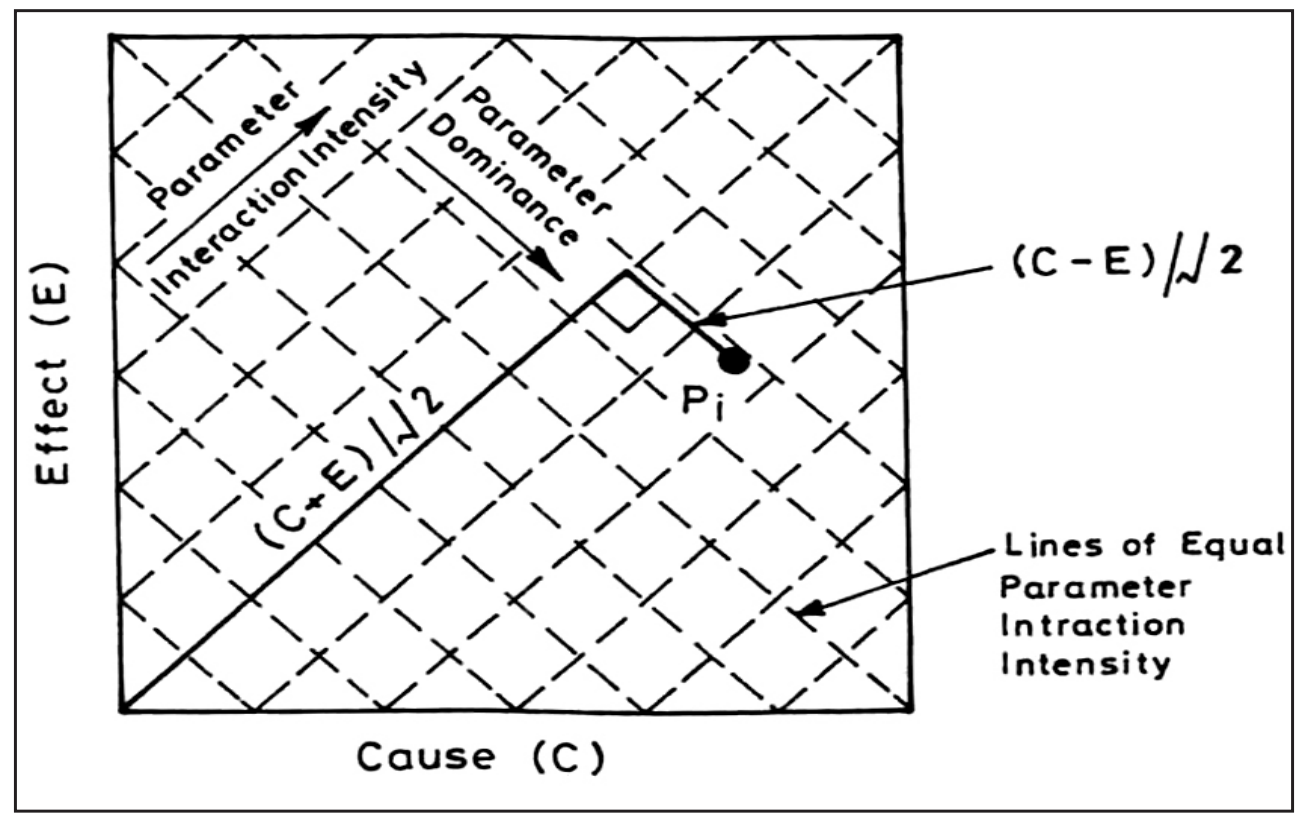

Fig. 3 Parameter interaction Intensity and Dominance (Hudson, 1992).

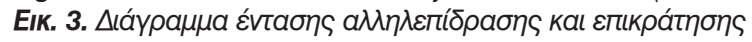

According to Hudson (1992), there are many "constellations" that could occur, the two main ones being mainly along the $\mathrm{C}=\mathrm{E}$ line or mainly along a line perpendicular to it. If the parameter points are scattered along the $\mathrm{C}=\mathrm{E}$ line but fairly close to it, then they can be ranked according to their parameter interaction intensity; in other words, they can be listed in order of interactive importance (Fig.4). If, on the other hand, the parameter points are scattered about a line perpendicular to the $\mathrm{C}=\mathrm{E}$ line, they will have similar interaction intensities but widely differing dominance values. In the former case, it might be possible to use, say, five or six parameters in such a scheme; in the latter case, all the parameters would have to be used.

The influential role of each parameter on slope failure (weighted of coefficient influence) is revealed from a cause versus effect diagram (Fig.6), while the role of system's interactivity is expressed from the histogram of the interactive intensity [cause (C) + effect (E)] against the parameters (Fig.7). These $\mathrm{C}+\mathrm{E}$ values (interactive intensity) will be transformed into a percentage form acting as weighting coefficients, which express the proportional share of each parameter (as a failure causing factor) in slope failure and normalized by dividing with the maximum rating (4), giving the ai\% (Fig.7).

Alternatively, there is another method for presenting the previous information (Fig.5), which is analogous to the hydrostatic and deviatoric axes of stress analysis (Hudson, 1992). This is via the co-ordinates $(C+E, C-E)$, which are the sum and the difference between the totals of the row and column values passing through a leading diagonal parameter. This method is a more direct identification of the most interactive parameter (having the largest $\mathrm{C}+\mathrm{E}$ value) and most dominant parameter (having the largest C-E value). 


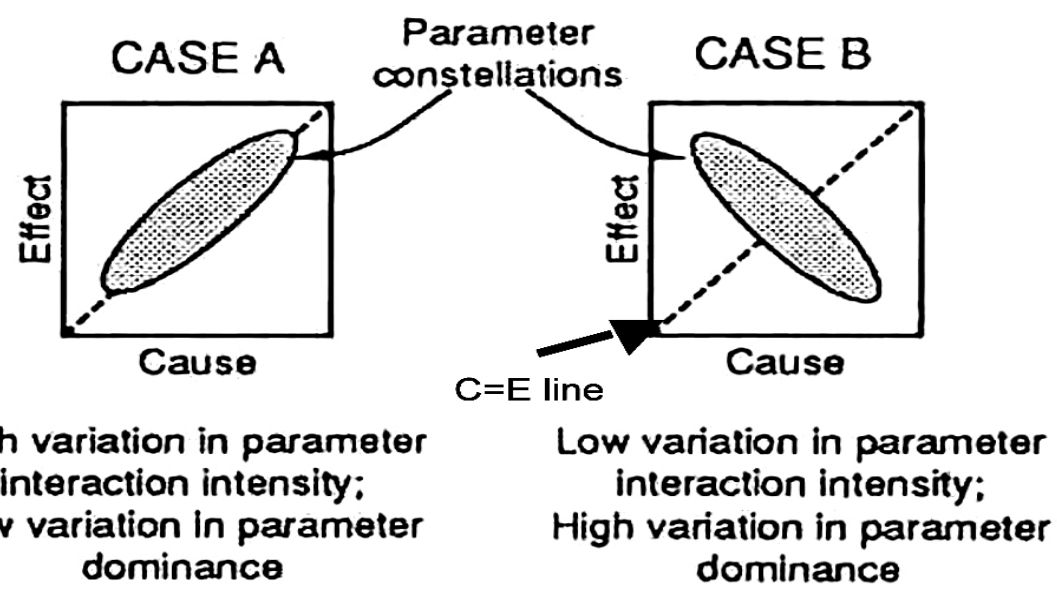

Fig. 4. The number of parameters required will depend on the form of the $C$ vs $E$ constellation. In case $A$ (constellation along the $C=E$ line), there is a wide range in parameter interaction intensity - so a few main parameters may be sufficient. In case $B$ (constellation perpendicular to the $C=E$ line), there is little range in parameter interaction intensity - so all the parameters will probably be required (Hudson, 1992).

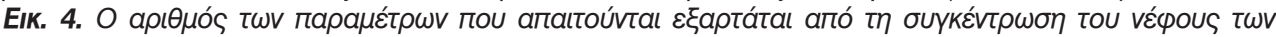

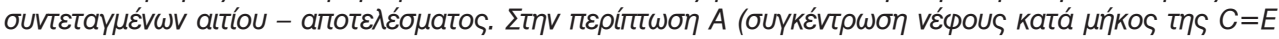

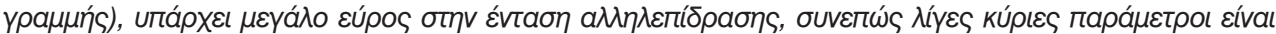

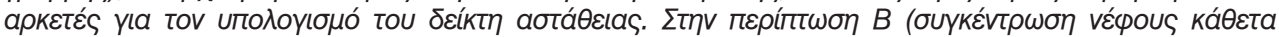

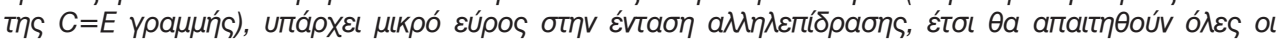

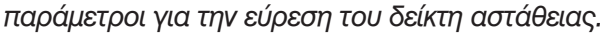

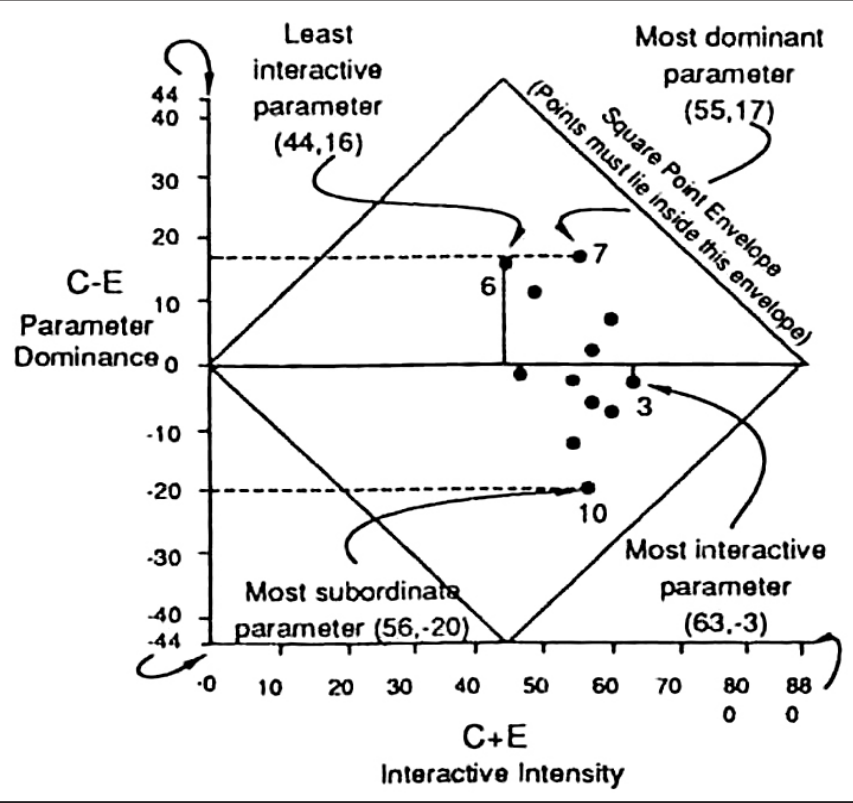

Fig. 5. Parameter points plotted in $C+E, C-E$ space so that parameter interaction intensity and dominance can be seen directly (Hudson, 1992).

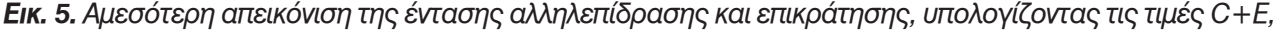

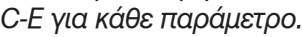




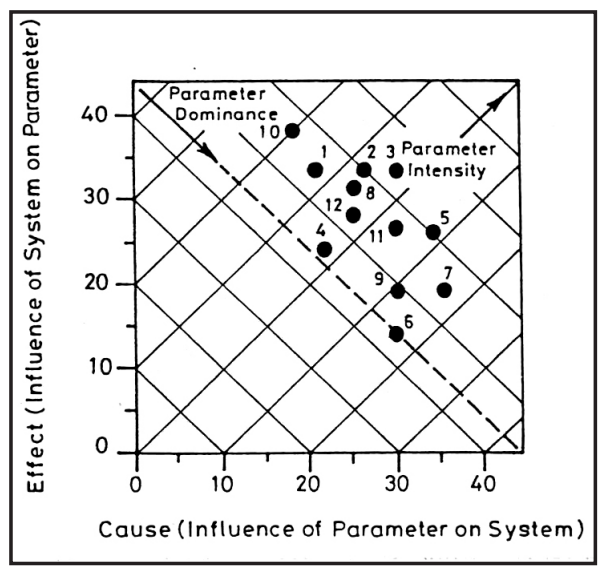

Fig. 6. Example of Cause vs effect plot [it refers to 12 parameters, (Hudson, 1992)].

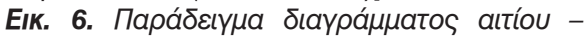

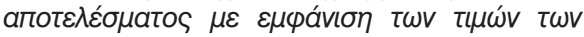

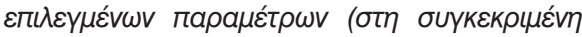

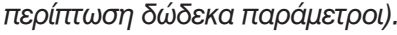

The next step is to compute the instability index (li) for the considered slope, by using the following equation:

$\mathrm{li}=\Sigma \mathrm{ai} \times \mathrm{Pij}$, where $\mathrm{i}$ refers to parameters (from 1 to 10), j refers to the examined slope and ai is the weighting coefficient of each parameter given by the formula:

$a i=1 / 4 *[(C+E) /(\Sigma i C+\Sigma i E)] \%$, scaled to the maximum rating of $\mathrm{Pij}$ (maximum value $=4$ ), $\mathrm{Pij}$ is the rating value assigned to the different category of each parameter's separation which also fits better to the conditions related to the parameter in question regarding the examined slope failure (Rozos et al., 2008).

The instability index is an expression of the inherent potential instability of the slope, where the maximum value of the index is 100 and refers to the most unfavorable conditions. As it will be estimated later, utilizing RES method in the examined slope of Tsakona area, the calculated instability index value is 71.88 , a value which according to Brabb et al., (1972) declares extremely high landslide susceptibility and this is confirmed from the slope failure that took place on February
Calculate the interactive intensity, $C_{i}+E_{i}$, for each parameter $P_{i}$

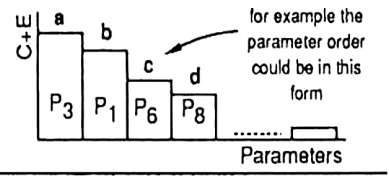

Choose the number of parameters required,

i.e. those contributing to say $80 \%$ or $90 \%$ of the $\Sigma(C+E)$ total

The required Instability Index is then:

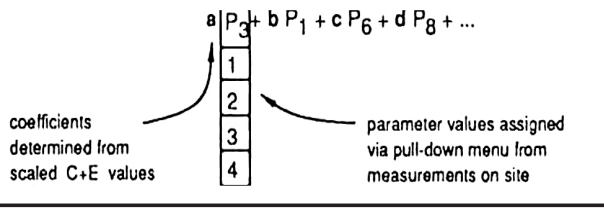

Fig. 7. Developing a slope instability index that takes into account the project objective and parameter interaction intensity (Hudson, 1992).

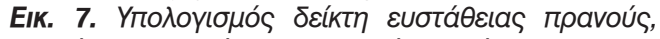

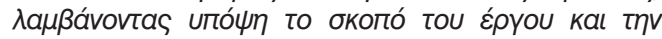

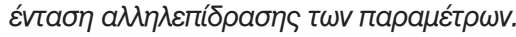

2003 in the particular study area of Tsakona.

Based on the above, RES has been developed by Hudson (1992) to determine interaction of a number of parameters in rock engineering design and calculate instability index for rock slopes. In this paper, an attempt is made to prove, how RES can be implemented with the same success in landslides (i.e. the Tsakona one), which are associated with a variety of geomaterials (such as soils, rocks, weathering mantle, etc) selecting each time the wider appropriate parameters that are relevant to the ad hoc potential slope failure.

Moreover, RES has been used, in this paper, for evaluating landslide susceptibility by adopting parameters that can be quantified easily than those of time and money consuming ones (like strength, etc). Besides, Hudson's theory, describes that an interaction matrix can be further analyzed to many more sub matrices, which means that the study of a site (concerning matrix construction) depends on the degree of analysis we are about to execute. 


\section{Geological setting of study area and selection of the parameters controlling the slope failure}

Tsakona landslide is the largest one that have ever affected the Greek National highway network as it entirely rubbed out the new Megalopolis - Kalamata highway at a length of $200 \mathrm{~m}$ (Fig. 8). This landslide was manifested in a site, where the tectonic deformation is very intense. There were old landslides before the activation of the last one and before the study and construction of the highway. The contractors as well as the consultant companies that studied the area did not take into account the already existed landslides (Fountoulis et al., 2007).

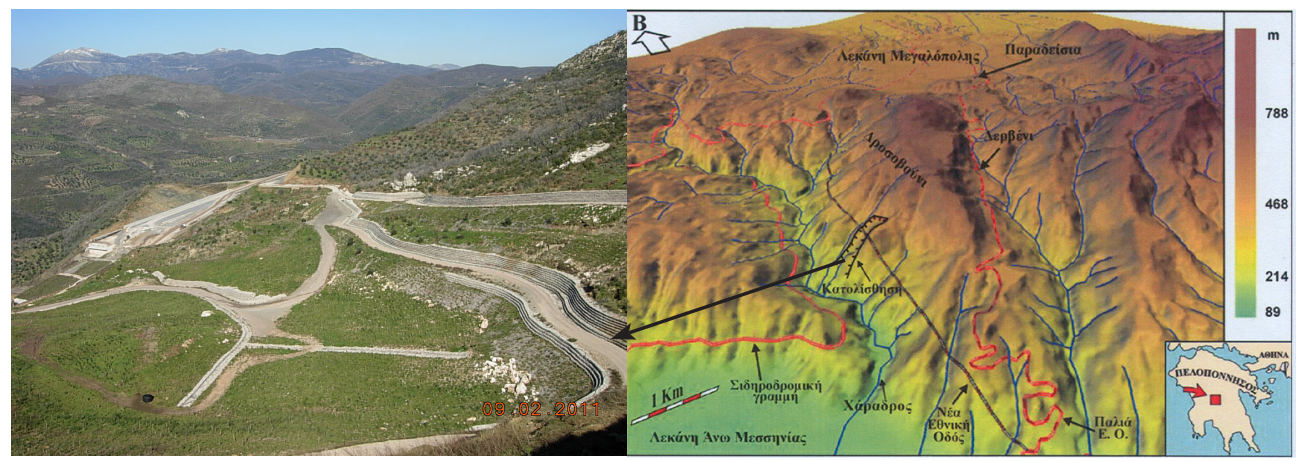

Fig. 8. Location map and shaded relief image showing morphology of the study area (Fountoulis et al., 2007).

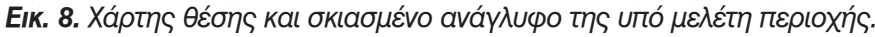

The geo-environmental properties of the site were determined by the use of geological, hydrogeological, morphological, engineering and environmental data obtained from the studies carried out in the region

(KEDE 2003; Sotiropoulos et al., 2004). From extensive geological and geotechnical investigation, it was revealed that two main categories of factors caused the slope failure were:

a) those which contributed to an unstable geological environment resulted in historical landslides again in the past such as lithology, intensive tectonics, hydrogeology and morphology,

b) those which triggered the landslide such as human intervention (concerning the construction of the National highway) and intensive rainfall during the winter of 2003 (Hellenic National Meteorogical Service, 2014).

In our case study area ten (10) parameters were selected as controlling factors for the landslide occurrence and each factor was classified into 4 classes. These factors which were utilized for the RES method are: (i) slope inclination, (ii) meteorological conditions (mainly rainfall), (iii) lithology, (iv) tectonic regime, (v) slope orientation (aspect), (vi) hydrogeology (vii), thickness of weathering mantle (viii) distance from roads, (ix) vegetation and ( $x$ ) distance from streams. Besides, the rating of each parameter is based on different researchers' studies from Greece, but adjusted to the local conditions of Tsakona landslide (Nakos 1984; Koukis and Ziourkas, 1991; Sotiropoulos et al 2004; Fountoulis et al, 2007; Rozos et al., 2008; Rozos et al., 2011; Boutina 
2012; River basin management plans, 2012; Farmakaki 2012).

\section{i) Slope inclination:}

The angle of the slopes has a great influence on the susceptibility of a slope to landsliding because they express the result of the combined influence of many factors such as the intensity of climatic conditions, the weathering processes and the internal geometry of geological formations (Rozos et al., 2008). To be more specific, slope gradient, at local scales, affects the concentration of moisture and the level of pore pressure, whereas at larger scales, it controls regional hydraulic continuity (Ayalew and Yamagishi, 2005). The morphology of the study area is characterized by a variety of types, which are associated with the intense tectonic regime of the surrounding area and the process of erosion taking place very close to the slope failure. Slope inclination which is determined by lithology, ranges between 5 to $10 \%$ (i.e. very close to the big Tsakona landslide), whereas the mean value slope inclination of the surrounding area is over $20 \%$ (Ministry of Public Works / Edafos Engineering Consultants S.A., 2003). The ranking of slope inclination is based on Koukis and $\mathrm{Zi}$ ourkas (1991), and the slope inclination value for the study area has been decided to be 1 (16-30o).

\section{ii) Meteorological conditions (mainly rainfall):}

Rainfall is cited as one of the most common landslide-triggering mechanisms. It increases both the groundwater level and the pore pressure in a soil mass / weathered mantle or aquifer. It has been noted that $50-60 \mathrm{~mm} / \mathrm{h}$ is sufficient to trigger a debris flow once the field capacity has been reached (Naga- rajan, 2001).

Generally, high precipitation is characterized as the physical processes constituting the main triggering causal factors of landslides (WP/WLI, 1994). In the study area, during winter of 2003, there was an extensive rainfall period which was basically one of the two most triggering factors for causing the slope failure. It altered the morphology of the surrounding area to a great degree (Dounias et al., 2006). The rating has been decided to take into account the experience from the relevant, locally encountered conditions (Hellenic National Meteorological Service, 2014) and the valuable knowledge of literature (Koukis and Ziourkas, 1991, Boutina 2012, Farmakaki, 2012). Moreover, the meteorological station of Diavolitsi (which is very close to the Tsakona landslide) shows a mean annual precipitation ranging from 1000 to $1400 \mathrm{~mm}$. From the above, the assigned value for the study area was decided to be 4 .

\section{iii) Lithology:}

The main source of data related to the geomorphology of a land is determined by the lithologic properties of it. Thus, lithology is one of the most important geological factors controlling landslide occurrence. It may be reasonably expected that ever since properties of the slope-forming materials such as strength and permeability are involved in the failure, that means are related to the lithology, which therefore should affect the likelihood of failure (Dai and Lee, 2002).

The study area is mainly covered by flysch, limestones, debris and earth fill deposits (Sotiropoulos et al., 2004). Particularly, the role of "schist-chert series', was crucial for the slope failure, since it contributed to the formation of a 
weathered zone with poor geomechanical properties and thickness range between 3 and $12 \mathrm{~m}$. Studying the geological history of the specific area of Tsakona, it should be mentioned that the presence of previous instabilities demonstrated the crucial role of lithology to the slope failure. To be more specific, older slides which took place in the layer of first flysch, contributed to the huge accumulation of limestone debris to the main body of landslide from the upper limestone. As this limestone was eroded in different geological periods, an extensive series of rockslides took place (Sotiropoulos et al., 2004). According to Koukis and Ziourkas (1991), concerning the statistical contribution of lithology to landslides for the whole Greek territory, lithology includes six classes as follows: (a) volcanic rocks, (b) cherts, schists, (c) limestones, marbles, (d) metamorphic formations exbiting schistocity, (e) loose soil formations (alluvial etc), (f) flysch. For the site specific area, the formation schist - chert was the representative class taking rate 1 .

\section{iv) Tectonic regime:}

Tectonic structures, such as thrusts and faults, are usually associated with extensive fractured zones and steep relief anomalies. These zones present favorable conditions for landslides (Kouli et al., 2010). Therefore, major structural discontinuities produced by faults and fractures were included as a parameter in this study. It has generally been observed that the probability of landslide occurrence increases at sites close to faults, which not only affect the surface material structures (Gemitzi et al., 2011) but also selective erosion and movement of water along faults planes promote slope instability (Foumelis et al.,
2004). The role of tectonics in Tsakona landslide was very important because it caused deterioration on the mechanical properties of the flysch formation, altered the morphology, not to mention the hydrogeological equilibrium of the whole area (Sotiropoulos et al., 2004). Based on Rozos et al (2008), tectonic regime analyzed in five classes: i) weak is connected with not a significant tectonic event, ii) moderate with the presence of schistocity, iii) strong is associated with the presence of faults and discontinuities, iv) very strong with high-fractured zones. Finally, the category intense represents up thrusts and over thrusts. According to Fountoulis et al (2007), the representative class of the study area is the category intense which constitutes the class with the higher rating (4).

\section{v) Slope orientation:}

The aspect of a slope can influence landslide initiation. Moisture retention and vegetation is reflected by slope aspect, which in turn may affect soil strength and susceptibility to landslides. If rainfall has a pronounced directional component by influence of a prevailing wind, the amount of rainfall falling on a slope may vary depending on its aspect (Dai and Lee, 2002). Besides, certain orientations are associated with increased snow concentrations and consequently longer periods for freeze and thaw processes (Rozos et al., 2008). Based on technical reports (Ministry of Public Works / Edafos Engineering Consultants S.A., 2003), the orientations $0-450$ and

135-225o, constitute the classes with the higher rating (4).

\section{vi) Hydrogeology:}

Generally, the infiltrated water increas- 
es the pore water pressure, causes swelling of some clay minerals and increases the weight of an unstable earth mass. In addition, its movement causes internal erosion or leaching and on the sliding surface plays the role of a lubricating agent (Varnes, 1984). In Tsakona area, the permeability of earth fill deposits and limestone debris was the main reason for the infiltration of the rainfall water and since it crossed the impermeable flysch, caused an increase in the pore water pressure with the known devastating results. It is mentioned that the rating of geological formation's permeability was based on River basin management plans (Ministry of Environment, Energy and Climate Change / Special Secretariat for water, 2012) and

(Rozos et al., 2008). Thus, according to them, the representative class is rating 2 (moderate) which corresponds to alluvial deposits and carbonate formations having low to medium permeability.

\section{vii) Thickness of weathering mantle:}

Another evaluation that is important from lithological point of view is related to the weathering degree of the units. In a study area there might be different weathering degrees in the same unit. At the same time the depth of weathered material might vary in different areas (Yalcin and Buluf, 2007).

Thickness of soil affects the rate of infiltration and the nature of slope movement (Foumelis et al., 2004). Some rocks weather more readily than others due to their mineral components, physical structure and exposure to exogenic geomorphic processes that may make them more prone to slope failure. Different rock types also have different shear strength and permeability, two factors that contribute to slope instability (Miller et al., 2009).

Weathered rocks and residual soils frequently contain montmorillonite, kaolinite and halloy-site clay minerals, which result in fissuring within the soil. The thickness of the weathered zone determines the ground recharge and fluctuation in water level. Thick and compact weathering profiles lead to perched water tables and slope stability (Nagarajan, 2001).

Concerning the study area of Tsakona, tectonic disturbances and failures that had taken place in the past, were responsible in producing large quantities of debris geomaterial and formulating such surfaces where the rainfall water could be gathered and consequently was able to be a potential agent for destabilizing the area's stability. As it has already been mentioned, the formation of a weathered zone with poor geomechanical properties and thickness ranges between 3 and $12 \mathrm{~m}$ and thus, the rating of the thickness of weathering mantle is four.

\section{viii) Distance from roads:}

Extensive excavation, application of external loads and vegetation removal are some of the most common anthropologically induced actions taking place along the road network slopes, during their construction. These attended actions are also responsible for the landslide triggering (WP/WPI, 1994). In addition, improper or uncontrolled discharge from sanitation or drainage works and water pipes, typically associated with human settlements and roads, especially in rural areas, which increase water infiltration in the slope, and possibly soil erosion at points of concentrated surface discharge are capable of causing landslides (Koumantakis, 2011). 
An important parameter that controls the stability of a slope is the construction of a road and particularly the closeness of the slopes to the roads. A given road segment may act as a barrier, a break in slope gradient or a corridor for water flow. In addition a road constructed on the side of the slopes causes a decrease in the load on both the topography and on the heel of slope. As a result of an increase in stress on back of the slope because of changes in topography and decrease of load some tension cracks may be created. On the slope of the hill that is balanced before the road is constructed, instability may be observed because of some negative effects such as water ingress (Yalcin and Bulut, 2007). Studying the role of human intervention in Tsakona landslide, it can be mentioned that there were a historical record of smaller failures during the construction of the National highway at the beginning of 1990's. Those slope failures gathered to give the major slope failure on February 2003. Based on the above but also according to Rozos et al (2011), the most prone class to landslide is that of $0-50 \mathrm{~m}$, taking the highest rate (4).

\section{ix) Vegetation:}

Vegetation plays an important role in controlling soil erosion and can help stabilize the slope by providing mechanical strength to the subsoil (Singhal and Srivastava, 2004). It provides a protective layer on the earth and regulates the transfer of water from the atmosphere to the surface, soil and underlying rocks (Greenway, 1987). In general, the stability of slopes is very sensitive in changes on vegetation cover (Rozos et al,
2008). Taking into account the standard criteria used by the Ministry of Agriculture for the evaluation of different sites (Nakos, 1984) and field observations, the moderate - grassland class characterizes site specific area (rating 2).

\section{x) Distance from streams:}

The closeness of the slopes to the stream structures is an important factor in terms of the stability. Streams may adversely affect stability by eroding the slopes or by saturating the lower part of material until water level increases (Gokceoglu and Aksoy, 1996).

In addition, maximum infiltration is observed on slopes adjacent to streams where the materials have maximum permeability (fragmented rock/colluvial deposits). Generally, as the distance from drainage line increases, landslide frequency decreases. This can be attributed to the fact that terrain modification caused (for example) by gully erosion may influence the initiation of landslides (Dai and Lee, 2002). At the site specific area, very close to the landslide area (less than $50 \mathrm{~m}$ ), there is Xaradros river and the assigned value for the study area was decided to be 4 .

The above aforementioned geodata were rated in order to be used in the construction of the interaction matrix. Studying the next table (Tabl.1), on the left side, each parameter rated from 0 to 4 and on the right side, it is mentioned where each parameter rating was based on. 


\begin{tabular}{|c|c|c|}
\hline \multicolumn{2}{|l|}{ RATING OF PARAMETERS } & \multirow[b]{2}{*}{ Notes - remarks } \\
\hline PARAMETERS & RATING & \\
\hline 1. Slope's inclination & & \multirow{6}{*}{$\begin{array}{l}\text { Even though, based on Koukis - Ziourkas (1991), the higher landslide density is in the class of } 16^{\circ}-30^{\circ} \text {, in } \\
\text { this study the higher rating was given to the slopes with the higher inclination, due to the fact that in nature, } \\
\text { slopes consisting of soil or hard soil to soft rocky formations and having high angle, fail almost immediately } \\
\text { after the formation giving lower slope angles (Rozos et al. 2011). }\end{array}$} \\
\hline $0-5^{\circ}$ & 0 & \\
\hline$\frac{0-5}{6-15^{\circ}}$ & 1 & \\
\hline$\frac{0-16-30^{\circ}}{16-1}$ & 2 & \\
\hline $31-45^{\circ}$ & 3 & \\
\hline$>45^{\circ}$ & 4 & \\
\hline \multicolumn{2}{|l|}{ 2. Rainfall } & \multirow[t]{6}{*}{ Based on Koukis - Ziourkas (1991), Boutina (2012), Farmakaki (2012). } \\
\hline$<400 \mathrm{~mm}$ & 0 & \\
\hline $400-600 \mathrm{~mm}$ & 1 & \\
\hline $600-1000 \mathrm{~mm}$ & 2 & \\
\hline$>1400 \mathrm{~mm}$ & 3 & \\
\hline $1000-1400 \mathrm{~mm}$ & 4 & \\
\hline \multicolumn{2}{|l|}{ 3. Lithology } & \multirow[t]{7}{*}{ Based on Koukis - Ziourkas (1991) for the period of 1949 - 1991.} \\
\hline Volcanic rocks & 0 & \\
\hline Cherts, schists & 1 & \\
\hline Limestone, marbles & 1 & \\
\hline Metamorphic formations exhibiting schistocity & 2 & \\
\hline Old landslide / disturbed geomaterial (alluvial, etc) & 3 & \\
\hline Flysch & 4 & \\
\hline \multicolumn{2}{|l|}{ 4. Tectonic regime } & \multirow{6}{*}{ Based on Rozos et al. (2008). } \\
\hline$\frac{\text { 4. Iectonic regime }}{\text { Weak }}$ & 0 & \\
\hline Moderate & 1 & \\
\hline Strong & 2 & \\
\hline Very strong & 3 & \\
\hline Intense & 4 & \\
\hline \multicolumn{2}{|l|}{ 5. Slope's orientation } & \multirow[t]{6}{*}{ Based on Rozos et al. (2008). } \\
\hline $225^{\circ}-275^{\circ}$ & 0 & \\
\hline $45^{\circ}-90^{\circ}$ & 1 & \\
\hline $90^{\circ}-135^{\circ}, 275^{\circ}-315^{\circ}$, & 2 & \\
\hline $315^{\circ}-0^{\circ}$ & 3 & \\
\hline $0^{\circ}-45^{\circ}, 135^{\circ}-225^{\circ}$ & 4 & \\
\hline 6. Hydrogeology & & $\begin{array}{l}\text { Based on River basin management plans (Ministry of Environment, Energy and Climate Change / Special } \\
\text { Secretariat for water, 2012) and Rozos et al. (2008). }\end{array}$ \\
\hline None & 0 & \\
\hline $\begin{array}{l}\text { Fractured formations characterised as having low to negligible permeability } \\
\text { (Flysch, schists) }\end{array}$ & 1 & $\begin{array}{l}\text { Restricted: refers to solution and leaching of soil materials as well as to the degradation of fine-grained and } \\
\text { coarse - grained materials. }\end{array}$ \\
\hline Alluvial deposits, carbonate formations having low to medium permeability & 2 & $\begin{array}{l}\text { Moderate: is associated with the freezing of water in the joints, the clays swelling and the action of water in } \\
\text { discontinuities and cavities. }\end{array}$ \\
\hline Debris with medium permeability & 3 & Increased: refers to erosion by water courses. \\
\hline Carbonate formations with medium to high permeability & 4 & $\begin{array}{l}\text { Extensive: is connected to the loading caused by snow, water of rainfalls and springs but also to the } \\
\text { increase of pore water pressure. }\end{array}$ \\
\hline \multicolumn{2}{|l|}{ 7. Thickness of weathering mantle } & \multirow[t]{6}{*}{ Based on Rozos et al. (2008). } \\
\hline None & 0 & \\
\hline Very small $(0,00-0,50 \mathrm{~m})$ & 1 & \\
\hline Small $(0.50-1.50 \mathrm{~m})$ & 2 & \\
\hline Medium $(1,5-3,0 \mathrm{~m})$ & 3 & \\
\hline Significant $(>3.00 \mathrm{~m})$ & 4 & \\
\hline \multicolumn{2}{|l|}{ 8. Distance from roads } & \multirow[t]{6}{*}{ Based on Rozos et al. (2011). } \\
\hline Distant (>200m) & 0 & \\
\hline Moderately distant $(151-200 \mathrm{~m})$ & 1 & \\
\hline Immediate $(101-150 \mathrm{~m})$ & 2 & \\
\hline Less immediate $(51-100 \mathrm{~m})$ & 3 & \\
\hline Close $(0-50 \mathrm{~m})$ & 4 & \\
\hline \multicolumn{2}{|l|}{ 9. Vegetation } & Based on Nakos (1984). \\
\hline No vegetation & 0 & \\
\hline Nil & 1 & \\
\hline Moderate - grassland & 2 & \\
\hline Agriculture & 3 & \\
\hline Intensive - agriculture & 4 & \\
\hline 10. Distance from streams & & Based on Rozos et al. (2011). \\
\hline Distant $(>200 \mathrm{~m})$ & 0 & \\
\hline Moderately distant $(151-200 \mathrm{~m})$ & 1 & \\
\hline Immediate $(101-150 \mathrm{~m})$ & 2 & \\
\hline Less immediate $(51-100 \mathrm{~m})$ & 3 & \\
\hline Close $(0-50 \mathrm{~m})$ & 4 & \\
\hline
\end{tabular}

Table 1. The selected parameters and their rating.

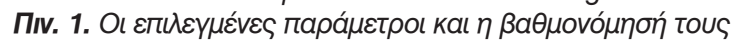




\section{Results and discussion}

In the present study, both geological and geotechnical information has been considered based on the previous ten (10) parameters and all the interactions that come out from this knowledge has been implemented through the interaction matrix. In the following session, the results of the application of RES method in Tsakona landslide are presented, such as the interactions of the examined principal parameters, the calculation of their weighting coefficients and finally the instability index accompanying with charts and tables which they decode and translate the aforementioned geodata.

Particularly, in Table 2, RES matrix for Tsakona landslide is given based on the rating of Table 1 and estimating the interactions among the examined parameters of the study area.

For example, let's take how rainfall affects hydrogeology. The runoff erodes the surface soil and weak rock formations. Also, the infiltrated water (water flow along discontinuities), increases the pore water pressure while affects the clay materials of the weathered mantle and consequently alters the hydrogeological properties of the existing geomaterials (rating: 4). On the other hand, hydrogeology does not influence rainfall at all (rating: 0 ).

The relation between interactive intensity against parameters is pictured in Fig.9, where it can be seen that lithology is the most interactive parameter $(\mathrm{C}+\mathrm{E}=38)$, while the slope orientation is the less interactive, which proves that it does not depend on the rest parameters' influence but is an independent agent concerning the whole system These are confirmed also in Fig. 4, but also by the outcomes of the extensive geological and geotechnical investiga- tion that took place after the landslide during the winter of 2003.

In Figure 10, the form of $C$ vs $E$ constellation in relation to $\mathrm{C}=\mathrm{E}$ line, defines the number of crucial parameters that will be needed for calculating instability index. So, according to Cause - Effect diagram (Fig.10), the form of the C vs $E$ constellation is perpendicular to the $\mathrm{C}=\mathrm{E}$ line, which means that (based on the aforementioned RES analysis) there is little range in parameter interaction intensity. On the contrary, there is a wide range in dominance

(C-E values), so all the selected parameters will be required for the calculation of the instability index of the examined slope, which is the main goal for constructing the RES matrix.

Finally, in Figure 11, the results of interactive intensity - dominance diagram agree with the findings from the geotechnical investigation that was executed after the Tsakona slope failure. According to Figure 11, the most dominant parameter is the rainfall since it was the main triggering factor for causing the Tsakona devastating landslide, while the less one is the weathering mantle, which means that it is depend on the influence of the other parameters.

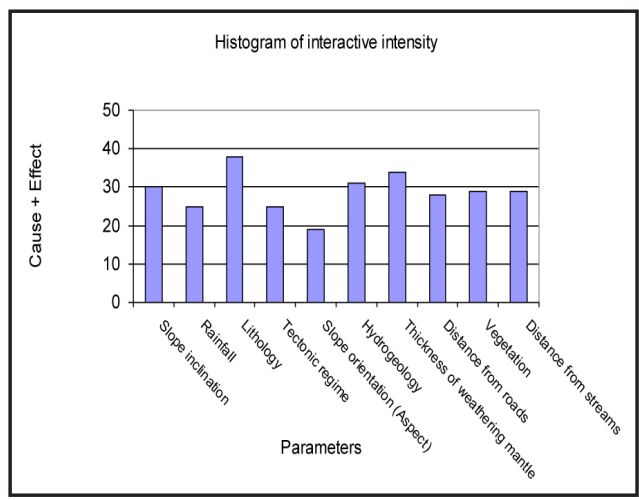

Fig. 9. Histogram of interactive intensity

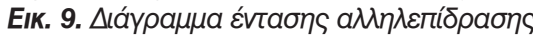




\begin{tabular}{|c|c|c|c|c|c|c|c|c|c|c|c|c|c|c|c|c|c|}
\hline \multicolumn{12}{|c|}{ Rock Engineering System (RES) - Tsakona Landslide } & \multirow[b]{2}{*}{$C+E$} & \multirow[b]{2}{*}{$C-E$} & \multirow[b]{2}{*}{ Parameters } & \multirow[b]{2}{*}{$\|(C+E) E(C+E)] 100 \%$} & \multirow[b]{2}{*}{ Maximum rating } & \multirow[b]{2}{*}{ weighted coefficient (a) } \\
\hline$\alpha^{\prime} a$ & 1 & 2 & 3 & 4 & 5 & 6 & 7 & 8 & 9 & 10 & CAUSE-C & & & & & & \\
\hline 1 & $\begin{array}{c}\text { Slope } \\
\text { incination }\end{array}$ & 0 & 1 & 0 & 1 & 1 & 2 & 2 & 1 & 2 & 10 & 30 & .10 & Slope incination & 10.42 & 4 & 2.60 \\
\hline 2 & 3 & Rainfal & 2 & 0 & 1 & 4 & 4 & 4 & 4 & 3 & 25 & 25 & 25 & Raintall & 8.68 & 4 & 2.17 \\
\hline 3 & 3 & 0 & Lithology & 2 & 3 & 4 & 4 & 4 & 4 & 3 & 27 & 38 & 16 & Ltthology & 13.19 & 4 & 3.30 \\
\hline 4 & 3 & 0 & 4 & $\begin{array}{l}\text { Tectonic } \\
\text { regime }\end{array}$ & 4 & 4 & 3 & 1 & 0 & 4 & 23 & 25 & 21 & Tectonic regime & 8.68 & 4 & 2.17 \\
\hline 5 & 2 & 0 & 0 & 0 & $\begin{array}{c}\text { Slope } \\
\text { orientation } \\
\text { (Aspect) }\end{array}$ & 0 & 2 & 1 & 2 & 1 & 8 & 19 & -3 & $\begin{array}{c}\text { Slope orientation } \\
\text { (Aspect) }\end{array}$ & 6.60 & 4 & 1.65 \\
\hline 6 & 2 & 0 & 1 & 0 & 0 & Hydrogeology & 3 & 1 & 2 & 3 & 12 & 31 & .7 & Hydrogedogy & 10.76 & 4 & 2.69 \\
\hline 7 & 2 & 0 & 0 & 0 & 0 & 2 & $\begin{array}{c}\text { Thickness } \\
\text { of } \\
\text { weathering } \\
\text { mantle }\end{array}$ & 2 & 2 & 1 & 9 & 34 & -16 & $\begin{array}{c}\text { Thickness of } \\
\text { weathering mantle }\end{array}$ & 11.81 & 4 & 2.95 \\
\hline 8 & 3 & 0 & 0 & 0 & 1 & 1 & 3 & $\begin{array}{c}\text { Distance from } \\
\text { roads }\end{array}$ & 3 & 1 & 12 & 28 & -4 & $\begin{array}{l}\text { Distance from } \\
\text { roads }\end{array}$ & 9.72 & 4 & 243 \\
\hline 9 & 2 & 0 & 2 & 0 & 0 & 1 & 2 & 0 & Vegetation & 2 & 9 & 29 & .11 & Vegetation & 10.07 & 4 & 2.52 \\
\hline 10 & 0 & 0 & 1 & 0 & 1 & 2 & 2 & 1 & 2 & $\begin{array}{l}\text { Distance } \\
\text { from } \\
\text { sirearms }\end{array}$ & 9 & 29 & -11 & $\begin{array}{l}\text { Distance from } \\
\text { streams }\end{array}$ & 10.07 & 4 & 2.52 \\
\hline EFFECT-E & 20 & 0 & 11 & 2 & 11 & 19 & 25 & 16 & 20 & 20 & & 288 & & & 100.00 & & \\
\hline
\end{tabular}

Where, weighted coefficient (ai) $=1 / 4$ * $[(C+E) /(\Sigma i C+\Sigma i E)] * 100 \%$

Table 2. Interaction matrix of the selected parameters of Tsakona landslide

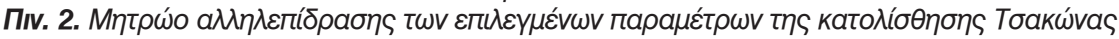

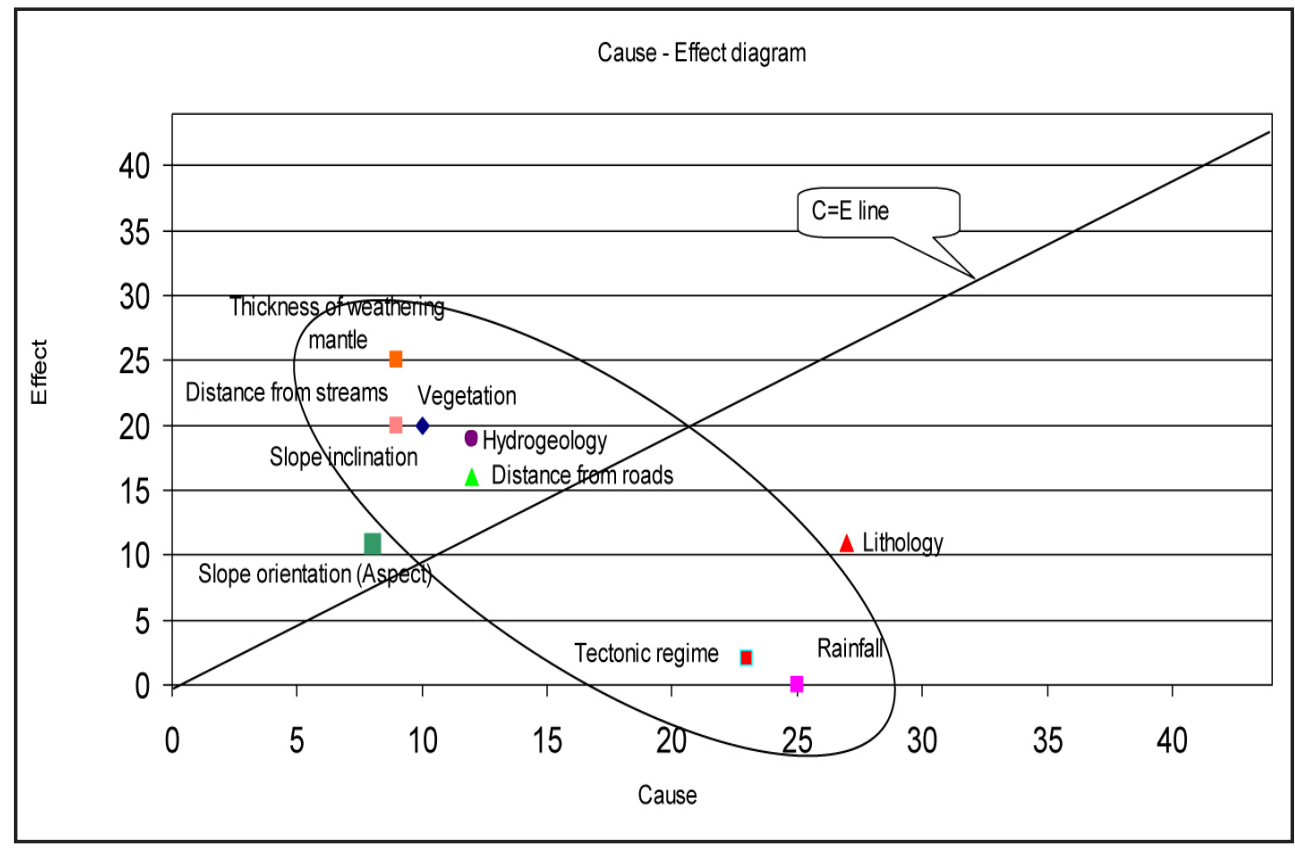

Fig. 10. Cause - Effect Diagram

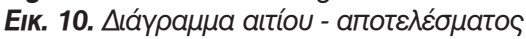




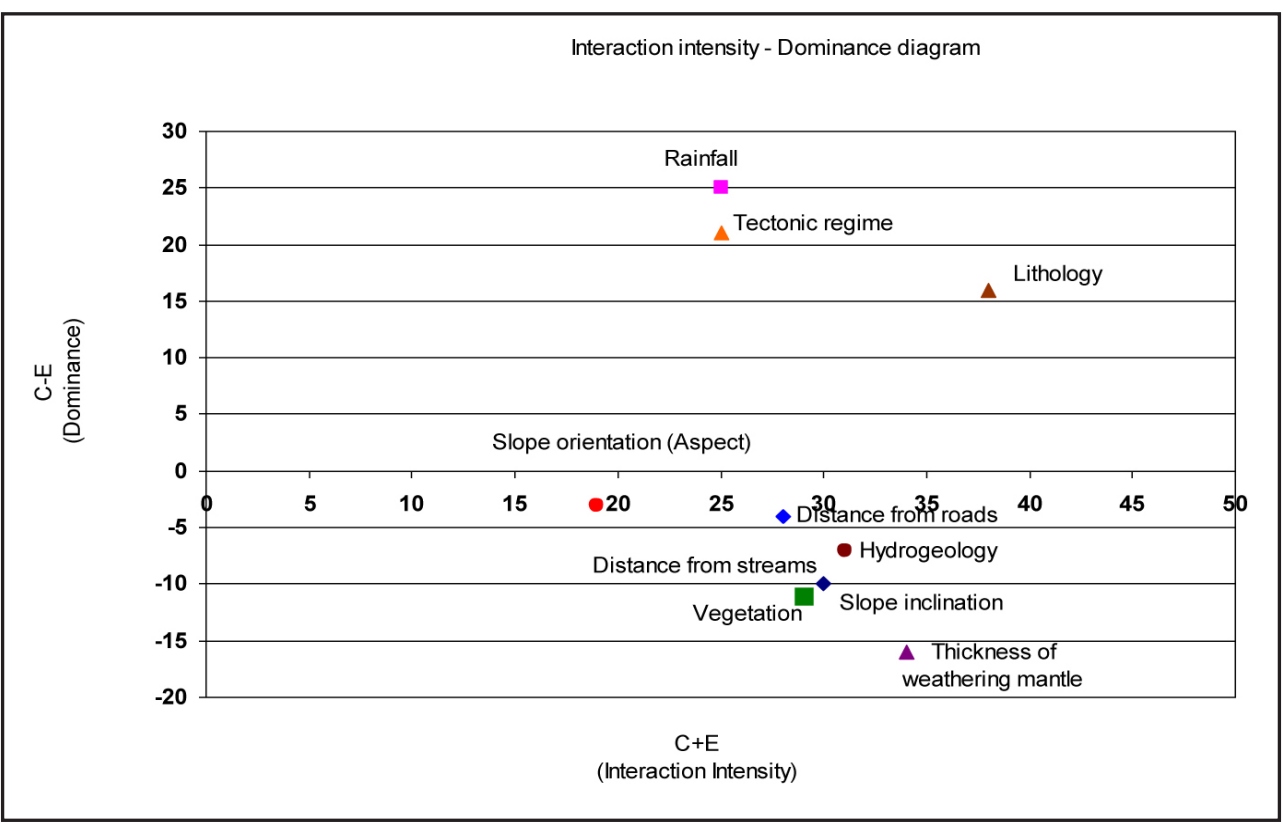

Fig. 11. Interactive intensity - dominance diagram

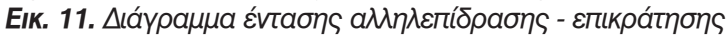

\begin{tabular}{|c|c|c|c|}
\hline Most interactive parameter & $(\mathrm{C}+\mathrm{E})_{\max }$ & 38 & Lithology \\
\hline Least interactive parameter & $(\mathrm{C}+\mathrm{E})_{\min }$ & 19 & Slope orientation \\
\hline Most dominant parameter & $(\mathrm{C}-\mathrm{E})_{\max }$ & 25 & Rainfall \\
\hline Most subordinate parameter & $(\mathrm{C}-\mathrm{E})_{\min }$ & -16 & $\begin{array}{c}\text { Thickness of } \\
\text { weathering mantle }\end{array}$ \\
\hline
\end{tabular}

Table 3. Maximum and minimum values of interaction intensity and dominance.

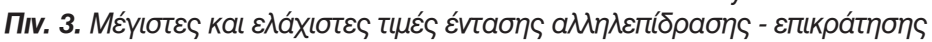

Supplementary, tables 4 and 5 decode and "translate" simultaneously the geodata acquired form the extensive geological and geotechnical investigation and contribute in giving the necessary objective answer to the prognosis of the potential instability of the examined slope of Tsakona landslide.

\begin{tabular}{|c|c|c|c|c|c|c|c|c|c|c|c|}
\hline \multicolumn{12}{|c|}{ Calculation of Instability I } \\
\hline Parameter & $\begin{array}{c}\text { Slope } \\
\text { inclination }\end{array}$ & Rainfall & Lithology & $\begin{array}{l}\text { Tectonic } \\
\text { regime }\end{array}$ & $\begin{array}{c}\text { Slope } \\
\text { orientation } \\
\text { (Aspect) }\end{array}$ & Hydrogeology & $\begin{array}{l}\text { Thickness of } \\
\text { weathering } \\
\text { mantle }\end{array}$ & $\begin{array}{l}\text { Distance from } \\
\text { roads }\end{array}$ & Vegetation & $\begin{array}{c}\text { Distance from } \\
\text { streams }\end{array}$ & $\begin{array}{c}\text { Instability Index } \\
\text { (ii) }\end{array}$ \\
\hline $\begin{array}{c}\text { Rating examined slope of } \\
\text { Tsakona }\end{array}$ & 1 & 4 & 1 & 4 & 4 & 2 & 4 & 4 & 2 & 4 & 71.88 \\
\hline Maximum rating & 4 & 4 & 4 & 4 & 4 & 4 & 4 & 4 & 4 & 4 & \\
\hline$[(C+E) / \Sigma(C+E)]^{*} 100 \%$ & 10.42 & 8.68 & 13.19 & 8.68 & 6.60 & 10.76 & 11.81 & 9.72 & 10.07 & 10.07 & 100.00 \\
\hline Weighted coefficient (a) & 2.60 & 2.17 & 3.30 & 2.17 & 1.65 & 2.69 & 2.95 & 2.43 & 2.52 & 2.52 & \\
\hline
\end{tabular}

Table 4. Calculation of Instability Index

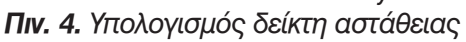


where:

Instability Index (li) = aai $\times$ Pij, where $\mathrm{i}$ refers to parameters (from 1 to 10 ), j refers to the examined slope and ai is the weighting coefficient of each parameter, Weighted coefficient (ai) $=1 / 4$ * $[(\mathrm{C}+\mathrm{E}) /(\Sigma \mathrm{i} \mathrm{C}+\Sigma \mathrm{iE})] \%$, scaled to the maximum rating of $\mathrm{Pij}$ (maximum val$\mathrm{ue}=4)$, $\mathrm{Pij}$ is the rating value assigned to the different category of each param- eter's separation which also fits better to the conditions related to the parameter in question regarding the examined slope failure (Rozos et al., 2008).

In Table 5, an explanation of rating the examined parameters of Tsakona landslide is presented, the information of which has been gathered and analyzed by studying the outcomes form the geological and geotechnical investigation.

\begin{tabular}{|c|c|c|}
\hline Parameter & Rating & Remarks \\
\hline Slope inclination & 1 & $\left(16-30^{\circ}\right)$ \\
\hline Rainfall & 4 & $\begin{array}{l}\text { According to Farmakaki (2012) and meteorological data from Hellenic National Meteorological } \\
\qquad \text { Service (2014) }\end{array}$ \\
\hline Lithology & 1 & $\begin{array}{l}\text { Schist -Cherts series: it was the most important lithology type that contributed mostly to the } \\
\text { slope failure }\end{array}$ \\
\hline Tectonic regime & 4 & Intense: represents up thrusts and over thrusts \\
\hline Slope orientation & 4 & $\left(0^{\circ}-45^{\circ}, 135^{\circ}-225^{\circ}\right)$ \\
\hline Hydrogeology & 2 & $\begin{array}{l}\text { Moderate: is associated with alluvial deposits, carbonate formations having low to medium } \\
\text { permeability }\end{array}$ \\
\hline $\begin{array}{l}\text { Thickness of weathering } \\
\text { mantle }\end{array}$ & 4 & Is bigger than $3 \mathrm{~m}$ \\
\hline Distance from roads & 4 & Close $(0-50 \mathrm{~m})$ \\
\hline Vegetation & 2 & Moderate - grassland \\
\hline Distance from streams & 4 & Distance from streams: Close $(0-50 \mathrm{~m})$ \\
\hline
\end{tabular}

Table 5. Explanation - description of rating the examined parameters of Tsakona landslide

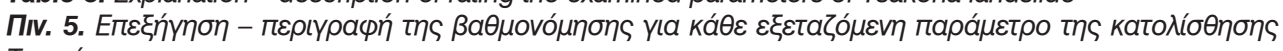
Tбakúvas

To sum up, the cause-effect plot is helpful to understand the role of each factor within a project and could be used in the decision-making stage. The cause and effect values for each parameter are used as $\mathrm{x}$ and $\mathrm{y}$ coordinates to plot the parameters in a cause $(C)$ versus effect (E) diagram. The more a system is interactive, the more the stability of a slope is low because there is more chance of a small variation in one parameter significantly affecting the system behavior. The computation of the level of interactivity via the $\mathrm{C}+\mathrm{E}$ value may be an indicator for identifying parameters whose variation is likely to induce significant changes in the system (Ceryan and Ceryan, 2008).

Based on the above and the calculated instability index value, Tsakona land- slide with $l i=71.88$ classified as ( $\mathrm{L}$ - landslide) according to the classification for landslide susceptibility by Brabb et al. (1972), as it shown in Table 6 . This is confirmed from the slope failure that took place on February 2003 in the particular study area of Tsakona. Concerning Brabb et al. (1972) classification, Chacon et al. (2006) wrote: "there is a lack of internationally accepted classifications and conventions for maps of spatial and spatial-temporal incidence of landslides. A common standard would be highly valuable for comparing maps, and also to classify the landslide areas all around the world in a manner similar to that used in, for example, seismic areas. A simple classification of landslide susceptibility is the averaged percentage of landslide fail- 
ure areas per total area of the region, by lithological or geological units, as proposed in the relative susceptibility num- bers of Brabb et al. (1972). This can give a simple scale ....".

\begin{tabular}{|c|c|c|c|c|c|c|c|}
\hline \% Failed area & $0-1$ & $2-8$ & $9-25$ & $26-42$ & $43-53$ & $54-70$ & 100 \\
\hline $\begin{array}{c}\text { Relative } \\
\text { Susceptibility }\end{array}$ & $\mathrm{I}$ & $\mathrm{II}$ & $\mathrm{III}$ & $\mathrm{IV}$ & $\mathrm{V}$ & $\mathrm{VI}$ & $\mathrm{L}$ \\
\cline { 2 - 7 } & Negligible & Low & Middle & High & Very high & $\begin{array}{c}\text { Extremely } \\
\text { high }\end{array}$ & Landslide \\
\hline
\end{tabular}

Table 6. Classification for relative landslide susceptibility proposed by Brabb et al. (1972)

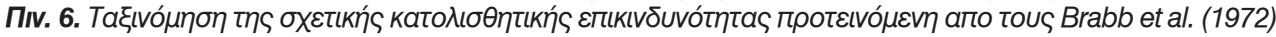

\section{Conclusions}

The implementation of the RES method has been achieved through an interaction matrix and it is believed it could be a very useful toolbox that can alert the designer to many mechanisms which previously might not have been taken into account. The study indicates that the interaction matrices methodology can be used to analyze the interactivity of numerous parameters which are factors in landsliding on slopes of various geological conditions in complex natural environments and has developed a procedure for the rapid assessment of the instability index. The validity of this approach was tested using the important landslide which happened on February 2003 and took place at Tsakona area of Prefecture of Arcadia which belongs to Region of Peloponnese. It is suggested that this procedure could be used in other regions. As it can be deduced from the process presented above, the advantages of the RES technique are: a) its adaptability to local conditions and to the given characteristics of existing geodata and expert's (geologist, civil engineer) knowledge and b) its ability to eliminate the exclusively subjected and arbitrary way regarding the selection of the parameters and the weighting coefficients by an expert, as it is the practice associated to other existing evaluation techniques (Rozos et a., 2008).
Although not demonstrated in the present paper, the method could be used in conjunction with Geographical Information Systems (GIS) approach which facilitates the manipulation of numbers of thematic map layers and can be useful in decision making, regarding the land use and development planning processes in landslide susceptible areas and thus providing a tool for zoning landslide hazard.

\section{References}

Ayalew, L., Yamagishi H., 2005. The application of GIS-based logistic regression for landslide susceptibiltiy mapping in the Kakuda-Yahiko Mountains, Central Japan. Geomorphology, 65, $15-31$.

Benardos, A., Kaliampakos D., 2004. A methology for assessing geotechnical hazards for TBM tunneling - illustrated by the Athens Metro, Greece, International Journal of Rock Mechanics and Mining Sciences.

Brabb, E., Bonilla MG, Pampeyan E., 1972. Landslide susceptibility in San Mateo County, California. US Geological Survey Miscellaneous Field Studies, Map MF-360, scale $1: 62,500$ (reprinted in 1978).

Boutina, N., 2012. Investigation of landslide phenomena which are triggered by rainfall in Greek territory. Dissertation, Charokopio University, 
Department of Geography, $107 \mathrm{p}$.

Cai, J., Zhao, J., Hudson, J., 1998. Computerization of rock engineering systems using neural networks with an expert system, Rock Mechanics and Rock Engineering, 31 (3), 135-152.

Ceryan, N., Ceryan, S., 2008. An application of the interaction matrices method for slope failure susceptibility zoning: Dogankent settlement area (Giresun, NE Turkey). Bull. Eng. Geol. Environ., 67, 375-385.

Ceryan, N., (2008). An application of the interaction matrices for slope failure susceptibility zoning: Dogankent settlement area (Giresun, NE Turkey). Bulletin of Engineering Geology and the Environment, 67, 3.

Chacon, J., Irigaray, C., Fernandez, T., Hamdouni, R., 2006. "Engineering geology maps: landslides and geographical information systems". Bulletin of Engineering Geology, 65, 341-411

Dai, F., Lee, C., 2002. Landslide characteristics and slope instability modelling using GIS, Lantau Island, Hong Kong. Geomorphology, 42, 213 228.

Dounias, G., Belokas, J., Marinos, P., Kavvadas, M., 2006. The big landslide of Tsakona at highway Tripoli - Kalamata. 5th Hellenic Congress Geotechnical and Geoenvironmental Engineering, Technical Chamber, Xanthi 31/05 - 02/06/2006

Farmakaki, A., 2012. Climate map of Greece. Master thesis, Master programme of Environment and Sustainable Development, NTUA, $75 \mathrm{p}$.

Foumelis, M., Lekkas, E., Parcharidis, I., 2004. Landslide susceptibility mapping by GIS-based qualitative weighting procedure in Corinth area. Bulletin of the Geological Society of Greece, XXXSI. 2004.
Fountoulis, I., Ladas, I., Mariolakos, I., 2007. Large scale landslide susceptibility mapping using gis-based weighted linear combination and multicriteria decision analysis - a case study in northern Messinia (SW Peloponnesus, Greece). Proceedings of 8th Congress of Greek Geographical Company.

Gemitzi, A., Eskioglou, P., Falalakis, G., Petalas, C., 2011. Evaluating landslide susceptibility using environmental factors, fuzzy membership functions and GIS". Global NEST Journal, 13 (1), 28-40.

Greenway, DR., 1987. Vegetation and slope stability. In: Anderson MG, Richards KS (eds) Slope stability. Wiley, New York, pp. $187-230$.

Gokceoglou, C., Aksoy, H., 1996. Slide susceptibility mapping of the slopes in the residual soils of the Mengen Region (Turkey) by deterministic stability analyses and image-processing techniques. Eng. Geol., 44, 147-161.

Hellenic National Meteorological Service (meteorological data), 2014.

Hudson, J., 1992. Rock Engineering Systems: Theory and Practice. Ellis Horwood Limited.

Irigaray, C., Fernandez, T., Hamdouni, R., Chacon, J., 2006. Evaluation and validation of landslide-susceptibility maps obtained by a GIS matrix method: examples from the Betic Cordillera (southern Spain).

KEDE, 2003. Governmental public projects' laboratory.

Koukis, G., Ziourkas, C., 1991. Slope stability phenomena in Greece: a statistical analysis

Bull IAEG, 43, 47-60.

Kouli, M., Loupasakis, C., Soupios, P., Vallianatos, F., 2010. Landslide hazard zonation in high risk areas of 
Rethymno Prefecture, Crete Island, Greece. Nat Hazards, 52, 599-621.

Koumantakis, I., 2011. Technical report of landslide phenomena of Metsovo. Proposed measures of improvement, $16 \mathrm{p}$.

Miller, S., Brewer, T., Harris, N., 2009. Rainfall thresholding and susceptibility assessment of rainfall-induced landslides: application to landslide management in St Thomas, Jamaica. Bull Eng Geol Environ, 68, 539550.

Ministry of Public Works / Edafos Engineering Consultants S.A., 2003. Remediation study of Tripoli - kalamata's motorway troublesome sections (Paradeisia - Tsakona).

Nagarajan, R., 2001. Rapid assessment procedure to demarcate areas susceptible to earthquake - induced ground failures for environment management - a case study from parts of northeast India. Bull. Eng. Geol. Env., 61, 99-119.

Nakos, G., 1984. Mapping and evaluation of forest earth and grounds. 1st Scientific meeting Hellenic Society 29 of Soil Science, Nov. 29-30. Thessaloniki, Greece, pp. 73-81 (in Greek).

River basin management plans, 2012. Ministry of Environment, Energy and Climate Change / Special Secretariat for water.

Rozos, D., Pyrgiotis, L., Skias, S., Tsagaratos, P., 2008. An implementation of rock engineering system for ranking the instability potential of natural slopes in Greek territory. An application in Karditsa County. Landslides, 5: 261-270.

Rozos, D., Bathrellos, G., Skillodimou, $\mathrm{H} ., 2011$. Comparison of the implementation of rock engineering system and analytic hierarchy process methods, upon landslide susceptibility mapping, usin GIS: a case study from the Eastern Achaia County of Peloponnesus, Greece. Environ Earth Sci, 63, 49-63.

Singhal, P.K., Srivastava, P., 2004. Challenges in sustainable development. Ammol publication, India.

Sotiropoulos, L., Liberis, E., Sigalas, A., Ntouroupi, A., Provia, K., Dounias, G., 2004. Landslide at Tsakona area in Arcadia prefecture. Geological conditions and activation mechanism. Bulletin of the Geological Society of Greece, vol. XXXVI, 2004. Proceedings of the 10th International Congress, Thessaloniki, April 2004.

Van Westen, C.J., Fan Xuanmei, Huang Runqiu, 2010. SAFELAND - 7th Framework Programme Deliverable D2.2: Examples of international practice in landslide hazard and risk mapping. Assessing the state of art of landslide hazard and risk assessment in the P.R. of China. Work Package 2.1: Harmonisation and development of procedures for quantifying landslide hazard.

Varnes, D.J., 1984. Landslide hazard zonation: a review of principles and practice, United Nations International, Paris.

WP/WLI (International Geotechnical Societies' UNESCO Working Party on World Landslide Inventory) (1994). A suggested method for reporting landslide causes. Bull. Int. Assoc. Eng. Geol., 50, 71 - 74.

Yalcin, A., Bulut, F., 2007. Landslide susceptibility mapping using GIS and digital photogrammetric techniques: a case study from Ardesen (NE - Turkey). Nat Hazards, 41: 201 -226 . 